\title{
The Castle of Collalto at War: The Social Structure of the Garrison and the Organization of the System of Defence in 1373
}

Ondřej Schmidt / schmidt@phil.muni.cz

Ústav pomocných věd historických a archivnictví, Filozofická fakulta, Masarykova univerzita, Brno, CZ

\begin{abstract}
This paper focuses on a unique and yet overlooked source which offers an interesting insight into the daily life of a late-medieval Italian castle during a time of war. It is a list of the guards as well as the other defenders of the castle of Collalto (north of Treviso) from 1373, which also contains a set of rules for them. After a short introduction to the history of the Collalto family and a description of the source, the author offers some theories as to what circumstances and motives may have led the lord of the castle, Count Rambaldo IX di Collalto, to drawing up the document in question. Subsequently, the source is used to analyse the social structure of the garrison and the defence system of the castle of Collalto.
\end{abstract}

\section{Keywords}

War; Castles; the Counts of Collalto; the Castle of Collalto; Italy; Venice; Padua; Treviso; 14th Century; Late Middle Ages; Military History; Diplomatics

This study was written as part of the project GX19-28415X: "From Performativity to Institutionalization: Handling Conflict in the Late Middle Ages (Strategies, Agents, Communication)", financed by the Czech Science Foundation. 
In this paper, I will focus on one specific source only - a list of the guards and defenders of the castle of Collalto from 1373, which also contains a set of rules for the garrison. The document originally comes from the Italian region of Veneto, but it is kept at the Moravian Provincial Archive in Brno in the Czech Republic. This is perhaps the reason why the source has never attracted the appropriate attention from Italian scholars; it has only been briefly touched upon by Pier Angelo Passolunghi. On the other hand, Czech historians have completely ignored this document, apparently because it has nothing to do with the history of Bohemia. The aim of this paper is to analyse this remarkable and yet overlooked source, place it within its proper historical context, and show its potential usefulness for historians of the Middle Ages.

\section{The Counts of Collalto}

In order to provide some background, it is necessary to briefly introduce the main characters of this paper, i.e. the Collalto family. Despite not being particularly well-known, the Collalto are one of the oldest noble families in Europe. ${ }^{1}$ The traditional narrative considers the counts to be descendants of the Lombard nobility, but their "forefather", Rambaldo I, is only documented in the middle of the 10th century when he obtained some possessions next to the Piave River. This area on the border between the territory of Treviso and Ceneda was to represent the power base of the family for the next thousand years.

Rambaldo I managed to win favour with the new Saxonian dynasty and, in exchange for his loyalty, was rewarded with the administration of the comitatus of Treviso. As the count of Treviso, he became the direct representative and highest official of the king/ emperor of the Romans in his district, with important judicial and fiscal competences. From the outset, however, his authority in Treviso was overshadowed by other competitors: first by the local bishop, then, from the second half of the 12th century, by the newly established city commune. Therefore, by 1200 the power of the counts in the city and its territory was merely an empty title. Although the counts could not enforce their authority in Treviso, they still remained its citizens, had their palace there and actively

1 The history of the Collalto family has been the long-term research interest of Pier Angelo Passolunghi. See at least the synthesis Passolunghi, Pier Angelo: I Collalto. Linee, documenti, genealogie per una storia del casato. Italia veneta 5. Treviso 1987, and the recent article idem: I conti di Treviso tra destra e sinistra Piave (metà sec. XII-inizio sec. XIV). In: Treviso e la sua civiltà nell'Italia dei comuni. Convegno di studio, Treviso, 3-5 dicembre 2009. Ed. P. Cammarosano. Collana atti 2. Trieste 2010, p. 37-59. I am grateful to the author for sending me some of his publications. The following brief introduction on the family history of the Collalto is based mainly on Passolunghi's studies. Cf. also the recent exhibition catalogue $Z$ Trevisa do Brtnice. Př́běhy šlechtického rodu Collalto ukryté v českých archivech (katalog výstavy) - Da Treviso a Brtnice. Storie della famiglia nobile dei Collalto nascoste negli archivi cechi (catalogo della mostra). Edd. P. Elbel - O. Schmidt, in collaboration with S. Bárta. Brno 2019 (with an updated bibliography), and the new synthetic history of the Collalto family by Moro, Pierandrea: Collalto. Storia di un casato millenario. I libri di Viella 302. Roma 2018. 
participated in the city politics. The title of counts of Treviso - as in many other cases became hereditary within the family and was used as late as the 15 th century. ${ }^{2}$

Analogous to other comital and margravial dynasties, the counts had already started to build their rural dominion in the 10th century. Thanks to their prominent position and a series of imperial privileges, they soon managed to accumulate extensive landed property around the Piave, which was also exempted from the jurisdiction of the commune and subject directly to the emperor. During the 12th and 13th centuries, the family built or acquired the castles of Collalto and San Salvatore. According to tradition, the first of these was erected around 1100 while the second was in the possession of the counts from 1245, becoming their principal residence. In addition, we should not forget that the comital family founded several important monasteries in the region, such as the 11th-century Abbey of Sant'Eustachio di Nervesa. The shift of their effective power base from the city to the countryside was also reflected in the use of the predicate: in the course of the Trecento and the Quattrocento, the counts of Treviso gradually became the counts of Collalto and San Salvatore. Therefore, although their comital title survived, it was no longer related to the city with its district but was limited to the lordship of the family around the Piave. Henry VII's descent into Italy marked an important turning point within the consolidation process of the Collalto domain. In 1312, the king of the Romans issued a privilege for Count Rambaldo VIII, confirming him both his lordships (San Salvatore and Collalto), which had been transformed into imperial fiefs. From the legal point of view, the counts became direct vassals of the empire, or better, of the emperor, which was essential for later developments. ${ }^{3}$

In the second half of the Trecento the comital family was under considerable pressure. The turn of the 14th and 15th centuries is generally regarded as the period of formation of the so-called territorial or regional states. This complex process was marked by the expansion of the most important powers on the Apennine Peninsula, which evolved into autocratic signorie and principalities or oligarchical republics (Milan, Florence and Venice), which started to conquer the others in order to create a "more simplified" political geography of Italy in the mid-15th century. ${ }^{4}$ In the area of north-eastern Italy, the

2 Rando, Daniela: Dall'età del particolarismo al comune. In: Storia di Treviso II. Il medioevo. Edd. D. Rando - G. M. Varanini. Venezia 1991, p. 41-102; Bustreo, Gian Paolo: I conti di Treviso, funzionari dell'impero e dinasti territoriali (secoli X-XIII). In: 958-1998. I Collalto. Conti di Treviso, patrizi veneti, principi dell'Impero. Atti del Convegno, 23 maggio 1998, Castello di San Salvatore, Susegana. Ed. Circolo Vittoriese di Ricerche Storiche, Vittorio Veneto 1998, p. 69-84; Varanini, Gian Maria: Treviso dopo la conquista veneziana. Il contesto politico-istituzionale e il destino di un ceto dirigente. In: Treviso e la sua civiltà nell'Italia dei comuni, p. 429-471.

3 Passolunghi, P. A.: I Collalto, p. 43-60; Giusto, Gabriele: Le maggiori presenze signorili nel Cenedese e Alto Trevigiano (secoli X-XII). Master's Thesis. Università Ca' Foscari. Venezia 2011-2012, p. 27-54; Schmidt, Ondřej: Mezi snahou o hegemonii v Trevisu a budováním pozemkové domény na Piavě: hraběcí rod od 10. do počátku 14. století. In: Z Trevisa do Brtnice - Da Treviso a Brtnice, p. 17-27, or idem: Tra lo sforzo di egemonia a Treviso e la costruzione di un dominio territoriale sul Piave: la dinastia comitale dal X fino agli inizi del XIV secolo. In: ibidem, p. 29-36; for the monasteries founded by the Collalto, see also Passolunghi, Pier Angelo: Conti di Treviso e monasteri benedettini del medio Piave (secc. XI-XV). Benedictina 36, 1989, p. 47-88.

4 See Lazzarini, Isabella: L'Italia degli Stati territoriali. Secoli XIII-XV. Roma - Bari 2003; Tanzini, Lorenzo: Dai comuni agli stati territoriali. L'Italia delle città tra XIII e XV secolo. Storia Medievale - Strumenti e Sussidi 4. Noceto 2010; Varanini, Gian Maria: Aristocrazie e poteri nell'Italia centro-settentrionale dalla crisi 
Republic of St. Mark constituted the biggest "threat" to smaller communes and rural lordships. ${ }^{5}$

The Collalto gradually began to be "besieged" by Venice, which conquered Treviso in 1338/1339 along with some other neighbouring towns. The comital family, surrounded by Venetian territory, maintained a rather ambiguous relationship towards the Serenissima: despite their dominions being imperial fiefs and thus formally independent of the Republic, it would have been impossible to ignore the powerful neighbour. Therefore, throughout the Trecento the attitude of the Collalto to Venice ranged from open hostility to pragmatic loyalty. They were accepted as members of the Venetian patriciate as early as 1306; around the middle of the century they allied themselves with King Louis the Great of Hungary against Venice, but later changed sides once again, becoming adhaerentes of the Republic of St. Mark. ${ }^{6}$

A few remarks on how the Collalto archive came to Brno should also be added. From the outset it has to be stressed that this had nothing to do with contacts between the Collalto family and the Czech lands in the Late Middle Ages. In fact it was the result of the remarkable career of the 17th-century condottiero, Rambaldo XIII di Collalto, who successfully served the Habsburgs during the Thirty Years' War, and was recompensed for his services in 1623 with the lordship of Brtnice in the Margraviate of Moravia. Rambaldo, or perhaps his history-loving successor, Antonio Rambaldo di Collalto, had some of the medieval documents from the family archive transported from the castle of San Salvatore to Brtnice. From there in 1907 the whole collection was transferred to the Moravian Provincial Archive in Brno. Given the fact that the castle of San Salvatore was partially destroyed during the World War I and its archive was almost completely lost at that time, the documents in Brno represent an important source of information concerning the history of the Collalto family. ${ }^{7}$ It is purely coincidental that some medieval charters from the dispersed San Salvatore archive were later found in western Bohemia

comunale alle guerre d'Italia. In: Le aristocrazie dai signori rurali al patriziato. Edd. R. Bordone - G. Castelnuovo - G. M. Varanini. Roma - Bari 2004, p. 121-193; The Italian Renaissance State. Edd. A. Gamberini - I. Lazzarini. Cambridge 2012.

5 For the expansion of Venice towards the Terraferma, see Varanini, Gian Maria: Venezia e l'entroterra (1300 circa-1420). In: Storia di Venezia. Dalle origini alla caduta della Serenissima III. La formazione dello stato patrizio. Edd. G. Arnaldi - G. Cracco - A. Tenenti. Roma 1997, p. 159-236; Mallett, Michael E.: La conquista della Terraferma. In: Storia di Venezia. Dalle origini alla caduta della Serenissima IV. Il Rinascimento. Politica e cultura. Edd. A. Tenenti - U. Tucci. Roma 1996, p. 181-244.

6 Passolunghi, P. A.: I Collalto, p. 55, 60-67; idem: Le contee di Collalto e di San Salvatore. Gli statuti del 1581-83 e altre norme inedite. Collana della Fondazione Castello San Salvatore 1. Susegana 2002, p. 31-42; Varanini, G. M.: Venezia e l'entroterra, p. 191-192; Schmidt, Ondřej: Ve stínu Republiky sv. Marka: hrabata z Collalta a San Salvatore v letech 1339-1519. In: Z Trevisa do Brtnice - Da Treviso a Brtnice, p. 37-47, or idem: All'ombra della Repubblica di San Marco: i conti di Collalto e San Salvatore negli anni 1339-1519. In: ibidem, p. 49-56. Cf. also fig. 1.

7 See Passolunghi, Pier Angelo: Da conti di Treviso a conti di Collalto e S. Salvatore: Presenza politica e impegno religioso della più antica famiglia nobiliare del Trevigiano. Atti e Memorie dell'Ateneo di Treviso (= Atti e Memorie) 1, 1983/84, p. 7-38, esp. 13-14; idem: Nota sulla perdita dell'archivio Collalto. Atti e Memorie 5, 1987/1988, p. 7-19; Elbel, Petr - Schmidt, Ondřej: Předmluva. In: Z Trevisa do Brtnice - Da Treviso a Brtnice, p. 7-10, or iidem: Premessa. In: ibidem, p. 11-14. 
and are now preserved in the State Regional Archive in Rokycany. It is assumed that they were taken by an anonymous Czech soldier who participated in the sacking of the castle. ${ }^{8}$

\section{The source, its characteristics and origin}

We can now finally turn to our source..$^{9}$ It has the form of a long and narrow Italian parchment resembling a notarial instrument. The document is written on both sides in neat gothic documentary semi-cursive, containing a number of conventional abbreviations. ${ }^{10}$ Its text has a somewhat complicated structure with the single sections being divided graphically from each other by two or three horizontal lines and/or provided with a title. The simple datatio (the document was drawn up on 1st January 1373) is immediately followed by the list of the guards, entitled in an exhaustive manner as: Infrascripte sunt custodie deputate $a[d]$ custodiam castri Collalti et cum quo ordine et cum qua forma et in quo loco et ad quod officium et quo die debent venire. The individual guards' names are ordered according to their shifts in seven columns, while each one of them corresponds to a day of the week starting from Sunday. This is followed by another two lists of men who were to guard the walls and the gate. ${ }^{11}$

The next section starts with a new datatio (still 1st January 1373) and contains below a set of rules for the garrison, establishing its members' duties. These were divided according to the armed men's positions: instructions for those on the walls, in the hall, in the big tower etc. It is entitled: Infrascript(us) est ordo et regula datus et data predictis custodiis et scrivatis deputatis ad custodiam castri Collalti per dominum Rambaldum de Collalto, comitem Ter(visinum) [...]. On the dorse, we find another list starting with the same datatio and the following title: Infrascripti sunt homines deputati ad custodiam totius castri Collalti et in quibus locis pro defensione dicti castri cum suis armis. It contains the names of the armed men and their positions within the defence system of the castle. At the end, another list of defenders of the "new bastion" (bastia nova) was added on 1st April of the same year. ${ }^{12}$

It is not easy to label the source from the point of view of diplomatics, as it does not fit exactly into one of the traditional categories. At first sight, the document has a similar appearance to notarial instruments, but it is written on both sides and it lacks the usual

8 Pelant, Jan: Nejstarši listina na územi našeho státu. Předběžná zpráva o mýtském nálezu listin a pečetí z collaltovského rodinného archivu. Minulostí Rokycanska 5, 1969, p. 1-2; Passolunghi, P. A.: Da conti di Treviso, p. 14-15; Elbel, P. - Schmidt, O.: Předmluva, p. 8, or iidem: Premessa, p. 12-13.

9 Moravský zemský archiv v Brně, G 169 - Rodinný archiv Collaltů Brtnice (= MZA Brno, G 169 - RA Collalto), folder 101, no. 2025. The text is edited in the Appendix I of this article. For a description of the document, see Passolunghi, Pier Angelo: Nota storico-insediativa sulla località Collalto. Studi Trevisani 5/6, 1987, p. 13-20, esp. 17-19; Schmidt, Ondřej: Řád a soupis posádky hradu Collalto. In: Z Trevisa do Brtnice Da Treviso a Brtnice, p. 140-141, or idem: Regolamento e lista delle guardie del castello di Collalto. In: ibidem, p. 142.

10 For the paleographical consultation I am grateful to Prof. Dalibor Havel.

11 Appendix I: Scrivate deputate super muros castri Collalti ut infra per ordinem. [...] Custodie deputate ad lobiam pro custodia porte et tocius castri.

12 Ibidem: Ad custodiam bastie nove dato ordine die primo Aprilis in dicto millesimo. 
subscription and signetum of the notary. The text must have been written by a local notary in the service of the lord Collalto, but his name is not to be found in the text. ${ }^{13}$ Nor we can find here a seal or any other means of authentication. The hybrid content can be characterized as a mixture of instructions (self-defined as ordo et regula) ${ }^{14}$ and a list, with only the "chancery" clause being the aforesaid datatio. Therefore, the source does not have the form of a public document with long-term legal validity. On the contrary, it was evidently intended as a kind of improvised auxiliary instructions for the officials of the castle.

First of all, I shall try to answer the question of why and in what circumstances the document was drawn up by providing the necessary historical context. As has been already mentioned, it was issued on the order of Count Rambaldo IX di Collalto, son of Schinella V and signore of the castle of Collalto at that time, ${ }^{15}$ on 1st January 1373, while three months later it was further "updated". The date is extremely important here as it tells us that the document came into existence during the so-called "Border War" (guerra dei confini) between Francesco il Vecchio da Carrara, ruler of Padua, and the Republic of Venice. This conflict, whose immediate casus belli was a dispute over the frontier between the two states (hence the name), actually falls into the traditional hostility between the Paduan Carrara dynasty and Venice, apparent during the second half of the 14th and the beginning of the 15th century. In this case, Carrara managed to win over King Louis of Hungary to his side and subsequently the dukes of Austria, with the result that the Republic found itself in quite an alarming situation. ${ }^{16}$

In spite of that, the Collalto family - Rambaldo IX and his cousins, the brothers Ensedisio and (Marco) Carlo - proved loyal to the Serenissima at this time, which is confirmed by several letters issued by the Venetian Doge Andrea Contarini and addressed to them. These sources indicate that the counts even temporarily ceded some of their strategic castles to the Republic, which sent its troops there. ${ }^{17}$ On the other hand, it has

13 For the notaries active on the Collalto lordship and their registers, see Corradini, Corrado et al.: Archivio di Stato di Treviso. In: Guida generale degli Archivi di Stato italiani IV. Roma 1994, p. 727-754, esp. 743-745; Canzian, Dario: Signorie rurali nel territorio trevigiano al tempo della prima dominazione veneziana (1338-1381). In: Poteri signorili e feudali nelle campagne dell'Italia settentrionale fra Tre e Quattrocento: fondamenti di legittimità e forme di esercizio. Edd. F. Cengarle - G. Chittolini - G. M. Varanini. Quaderni di Reti Medievali Rivista 1. Firenze 2005, p. 227-248, esp. 237, 239 and 247, note 68.

14 In the context of Bohemia, similar instructions for the captain of the castle of Křivoklát from the early 16th century were edited and analysed by Boukal, Jan: Hospodářská instrukce jako pramen poznáni života na hradech na prahu raného novověku (Na př́kladu instrukce pro křivoklátského hejtmana Albrechta z Vřesovic z roku 1528). Castellologica Bohemica 17, 2017, p. 155-171. In this case, however, the document was originally authenticated by a secret seal.

15 For some information about Count Rambaldo IX, see the 18th-century treatise La Genealogia dell'antichissima e nobilissima Famiglia de' conti, poscia de' conti di Treviso e dappor de' conti di Collalto etc. dall'anno di nostra salute 570, edited in Passolunghi, P. A.: I Collalto, Appendix, p. 206-207.

16 For the conflict, see Sambin, Paolo: La guerra del 1372-73 tra Venezia e Padova. Archivio Veneto, Serie V, 76/77, 1948, p. 1-76; Kohl, Benjamin G.: Padua under the Carrara 1318-1405. Baltimore 1998, p. 119-126; Varanini, G. M.: Venezia e l'entroterra, p. 199-200.

17 MZA Brno, G 169 - RA Collalto, folder 322; cf. Serie cronologica di tutti i privilegi concessi e riconfermati alla famiglia dei conti di Collalto e San Salvatore ec. Venezia 1798, p. 20. For the correspondence from the subsequent period of the War of Chioggia (1378-1381) during which the Collalto chose once again the side 
to be pointed out that there is also an account from a chronicle written by members of the Paduan Gatari family which does not fit in with this picture. According to this source, in March 1373 the Hungarian troops plundered the Collalto dominions. Later on, however, the count sent a statement to the commander of the Hungarians that he was a "friend and loyal follower of the lord of Padua", whereupon he received his stolen plunder back. ${ }^{18}$ There are basically two ways to interpret this contradiction: either the Gatari chronicle is completely (and intentionally?) wrong in its narration, or the Collalto did indeed try to remain formally neutral and maintain good relationships with both belligerent powers.

It is not necessary to go in detail into the course of the war, which lasted from October 1372 to September 1373; instead I will focus on one single event which occurred on 9th December 1372, which in my opinion clarifies the motives for the issue of the list of guards and the instructions for them. At that time, the Hungarian army had finally arrived in Italy via Friuli to help their Paduan ally. Once they had passed the Patriarchate of Aquileia and entered the territory of the Republic, they fought the Venetian army led by Taddeo Giustinian at the Piave River. Given the contradictory accounts in the various narrative sources, the details are not entirely clear, but it seems that the battle took place close to the Abbey of Sant'Eustachio di Nervesa, which was almost in sight of the castle of Collalto, while at least some of the Hungarian units must have certainly crossed the territory of the counts. The sources do not reveal whether some members of the Collalto family engaged directly in the fighting, but they are unanimous in the assertion that the Venetians suffered a heavy defeat, with Taddeo Giustinian and some other nobles being taken captive and brought to Padua and later to Hungary. ${ }^{19}$ After the battle, the Hungarians moved further west, leaving the lordships of Collalto and San Salvatore, which do not seem to have been directly involved in the rest of the conflict.

Nevertheless, I believe that it was this devastating defeat of the allied Venetian army and the imminent danger of an assault from the enemy that persuaded Rambaldo di Collalto to ensure the better defence of his castle and, as a result, to issue the document containing the list of the guards with instructions for them only two weeks later. In fact, the Collalto dominions were not even safe after the battle at the Piave when the Hungarians moved west. For example, the Venetian chancellor Raffaino de' Caresini claimed

of Venice, see also Schmidt, Ondřej: Listy benátských dóžat z doby války o Chioggiu. In: Z Trevisa do Brtnice - Da Treviso a Brtnice, p. 158-163, or idem: Lettere dei dogi di Venezia dell'epoca della guerra di Chioggia. In: ibidem, p. 163-164.

18 Cronaca Carrarese di Galeazzo e Bartolomeo Gatari, confrontata con la redazione di Andrea Gatari [AA. 13181407]. Edd. A. Medin - G. Tolomei. Rerum Italicarum Scriptores - Nova Series (= RIS NS) XVII/1a. Città di Castello 1909, p. 94: Come messer Benedetto Ongaro corse su quello di Collalto et a Conegiano. Deseotto di marzo, misser Benedetto Ongaro chavalcò versso Colalto e verso San Salvadore e altre castelle e ville dil conte da Cholalto, e tute le rubò e prese di molti presoni: le qual cosse sentendo il conte da Colalto, per suo messo notificò a misser Benedetto come lui era amigo e fedelle dil signore di Padoa e che di ciò lui si faciea maraviglia. Misser Benedetto, udendo si fatta cosa, comandò che di presente fusse ogni cosa restituito, e cosi fu fatto [...]. For the chronicle and its authors, see Arnaldi, Girolamo - Capo, Lidia: I cronisti di Venezia e della Marca Trevigiana. In: Storia della cultura veneta II. Il Trecento. Ed. G. Arnaldi. Vicenza 1976, p. 272-337, esp. 331-336.

19 See the reconstruction of events by Sambin, P.: La guerra, p. 35-37, who gathered and analysed all the relevant sources. 
that the mercenaries in the service of the Republic sojourning in the Trevigiano actually "caused greater damage to our subjects than our enemy". ${ }^{20}$ Therefore, the lord of the castle of Collalto could not even trust the allied Venetian troops. This hypothesis is also indirectly confirmed by a note on the margin of the document, explicitly specifying that it was drawn up "during the war between the Ducal domination [i.e. Venice] and the lord of Padua". ${ }^{21}$ It has to be stressed, therefore, that the document was clearly reacting to an exceptional warlike situation - the imminent assault of the castle - so its validity must have been limited to how long the war lasted.

So far, the document has been used for practically one purpose only: for a reconstruction of how the castle of Collalto looked at the end of the 14th century. As it contains many records regarding the position of individual guards, it is possible to say that the castle had a "big tower", preserved to this day, as well as several smaller ones, the count's palace, residential houses and churches or chapels, walls, some bastions, gates and even a tavern. ${ }^{22}$ In this regard, it may be pointed out that in April 1373 a new list of the guards of the "new bastion" was added, which means that Count Rambaldo probably had this fortification built in the first months of the year in order to reinforce the defence of the castle. However, the following analysis will focus more on two other aspects which can also be analysed using this source: on the one hand, I will attempt to uncover the social structure of the castle's garrison and, on the other, to reconstruct its system of defence.

\section{The social structure of the castle garrison}

The main task is to make sense of the groups of people indicated in the different lists. For various reasons this is not easy: the lists do not correspond with each other, some people are indicated on one list only, some on two; their names do not appear in a consistent form and the identification of some guards is impossible. In general, there seems to be no pattern at first sight. However, we have another source at our disposal that may be helpful in deciphering the lists - the registers of the local notary Bartolomeo di Bernardo da Barbisano who was active in Collalto and the surrounding area from 1373 to

20 Raphayni de Caresinis cancellarii Venetiarum Chronica AA. 1343-1388. Ed. E. Pastorello. RIS NS XII/2. Bologna 1922, p. 24-25: Exercitus noster generalis rediit ad Tarvisinum districtum, commoratusque est pluribus diebus apud suburbia Tarvisina, maiora quam hostes damna inferens fidelibus nostris [...]. For Caresini's chronicle, see Arnaldi, G. - Capo, L.: I cronisti di Venezia, p. 291-296.

21 Appendix I: [...] continens custodias omnes deputatas pro custodia [ca]stri Collalti millesimo CCCLXXIII, tempore [gu]ere inter dominacionem ducalem et dominum Padue.

22 See Passolunghi, P. A: Nota storico-insediativa, p. 17-19; idem: I Collalto, p. 55, note 45; idem: Le contee di Collalto, p. 58-59. Cf. also the reconstruction of the castle of Collalto in Potocnik, Michele - Salvador, Antonio: Collalto, il castello delle origini, e la chiesa di San Daniele di Colfosco o di San Salvatore. In: 958-1998. I Collalto, p. 19-34, esp. 23 (reproduced here as fig. 2), and Passolunghi, Pier Angelo: Catalogo per Susegana. Italia veneta 6 . Susegana 1989, p. 186, fig. 72. A good idea of how the castle looked in the early 16th century can be discerned from the famous painting Madonna col Bambino fra i santi Michele Arcangelo $e$ Andrea Apostolo by Cima da Conegliano, kept in the Galleria Nazionale in Parma (according to older interpretations, however, the castle depicted is actually to be identified with a similar-looking one in Conegliano). 
1375. In his acts, it is possible to find many people from our lists and as a result there is more information about their social background. ${ }^{23}$

The first list contains castle guards without any specific position: each day of the week, 18 men came to serve. That makes 126 names in total for the whole week. However, some of them are apparently listed twice in different days, so the overall number of men guarding the castle was slightly lower. It is not possible to identify everyone from this group, but according to their epithet, most of them came from the surrounding villages which were subject to the castle of Collalto. ${ }^{24}$ Some of them are identified by their profession, such as tailor (sartor), shoemaker (calegarius) or pelterer (peliparius). Only a few of them have the abbreviation of Ser in front of their name, indicating that they were probably notaries, while one name is preceded by the title of magister. Therefore, it seems that most of these people were subjects of the Collalto lordship, who had to serve once or twice a week as guards at the castle as part of their duties towards the lord. Furthermore, as both the subsequent lists and the notarial registers of Bartolomeo da Barbisano show, none of these men seems to have been a member of the garrison or an inhabitant of the castle. ${ }^{25}$

The second list indicates only four guards a day, making 28 men in total for the whole week. It is necessary to add that these people are not the same as those from the first list. Unlike the first group of men, referred to as custodie, these people are called scrivate, who were supposed to patrol the walls. ${ }^{26}$ It is impossible to find this word in Latin dictionaries, ${ }^{27}$ but the function of these people as guards is quite evident. On the one hand, there were some more notable persons among them, such as dominus Rambaldus, dominus presbyter Bartholomeus and dominus frater Franciscus. The identification of Rambaldo is quite obscure: he was either the lord of the castle himself, Count Rambaldo IX (but it is doubtful he would have had the same ordinary watch as the others), or someone else. In another list on the dorse of the document, there is a group of people responsible for the defence of Count Rambaldo, with the first one of them being another Lord

23 Archivio di Stato di Treviso (= ASTv), Notarile, I, b. 33, Atti di Bartolomeo di Bernardo da Barbisano.

24 See also Passolunghi, P. A: Nota storico-insediativa, p. 19: "Segno di una partecipata vita amministrativamente sottoposta al castello [...] ai compiti della difesa comune concorrevano pure le vicine località che il diploma di Arrigo VII del 1312 aveva sottoposto alla giurisdizione comitale di Collalto." Cf. idem: Le contee di Collalto, p. 58-59. The villages belonging to the castle of Collalto (Collalto, Falzè, Sernaglia, Barbisano and Refrentolo) are listed in the privilege of King Henry VII from 1312, edited in idem: I Collalto, Appendix, p. 126-127, no. 11; for a description of this important document and its preservation, see also Vetterová, Šárka: Listina Jindřicha VII. pro hraběte Rambalda VIII. In: Z Trevisa do Brtnice - Da Treviso a Brtnice, p. 113-116, or Eadem: Il diploma di Enrico VII per il conte Rambaldo VIII. In: ibidem, p. 116-117.

25 See below. Johannes sartor, present in this list, is probably not Johannes sartor de Arca, whose house was in the castle. Bartolomeo's registers report that Ser Benucius lived in the village of Collalto: ASTv, Notarile, I, b. 33, Atti di Bartolomeo di Bernardo da Barbisano, f. 26r: [...] Ser Benucio quondam Ser Cardineli de villa Collalti $[\ldots]$ (25th April 1375).

26 Appendix I: Scrivate deputate super muros castri Collalti ut infra per ordinem.

27 It may have been a local Italian word, translated into Latin, but I was unable to identify it. Perhaps it can be translated as "those who are registered on the list" (for this suggestion I am grateful to Prof. Pier Angelo Passolunghi). However, even if we accept this interpretation, the terminological distinction between the custodie and scrivate, both listed in the document, is not clear. 
Rambaldo. Because of the prominent position on the list and the title of dominus he must have been a noble; given his name, which was traditional within the Collalto family, he seems to have been a family member. Hypothetically, he could have been a homonymic son of Count Rambaldo and, as he does not appear in the Collalto genealogy, he might have been a bastard..$^{28}$ But this is all speculation. As for the two clergymen, thanks to the same list on the dorse, Bartolomeo can be identified as a parish priest in Barbisano, while Brother Francesco was undoubtedly a commander of the Order of St. John of Jerusalem (there was also a commandry of this order at the castle). ${ }^{29}$ Francesco also appears in the registers of the notary Bartolomeo da Barbisano. ${ }^{30}$ Next to them, however, there were many craftsmen. In addition, the set of rules implies these scrivate were given some extra responsibilities and were also to supervise the other guards. Therefore, it is possible to surmise that these men were inhabitants of the castle. This can be proven for at least eight of them mentioned here or in the subsequent lists with the epithet de Arca, i.e. literally "from the castle". ${ }^{31}$ Moreover, the house of the blacksmith called Merchadantus was also in the castle. ${ }^{32}$

Another list of custodie is composed of men who were to serve in the hall (lobia) and probably in the court of the castle next to the gate. ${ }^{33}$ However, these people were not identically the same as those from the preceding two lists. Each day there were four of them, but the complete number is only 25 , as in three cases the list contains an empty space. Because of their origin, it seems that most of these armed men were mercenaries in the service of Count Collalto, sojourning at the castle. Some of them were from the Veneto (Padua, Cesana, Onigo), but many came from neighbouring Friuli (San Daniele, Sacile, Attimis, Faedis) and there were also two "Germans" (Teotonici), with one of them being cited twice on two different days. Once again, some of them had the epithet $d e$

28 For the position of aristocratic bastard sons as officials or vassals on their fathers' dominions, see e.g. Spiess, Karl-Heinz: Familie und Verwandtschaft im deutschen Hochadel des Spätmittelalters. 13. bis Anfang des 16. Jahrhunderts. Vierteljahrschrift für Sozial- und Wirtschaftsgeschichte 111. Stuttgart 1993, p. 383-386; Hurwich, Judith J.: Bastards in the German Nobility in the Fifteenth and Early Sixteenth Centuries: Evidence of the Zimmerische Chronik. Sixteenth Century Journal 34/3, 2003, p. 701-727, esp. 722.

29 See Passolunghi, P. A.: I Collalto, p. 50: "Nel castello di Collalto sorse invece l'ospedale di San Giovanni di pertinenza dell'ordine gerosolimitano, possessore di altre case dislocate nel Trevisano e verso il quale la famiglia comitale fu costantemente legata."

30 ASTv, Notarile, I, b. 33, Atti di Bartolomeo di Bernardo da Barbisano, f. 3r: [...] presentibus religioso et honesto viro domino fratre Francisco, preceptore domus de Collalto ordinis sancti Johannis Jerosolimitani [...] (8th February 1373). In the same document is also Bartolomeo, a parish priest in Sernaglia, who does not seem to be the person with the same name in our list, a parish priest in Barbisano.

31 These were: Blasius sartor, Leonardus de Arca, Bartholomeus Taxinonus, Bartholomeus quondam Hensedisii, Johannes calegarius, Johannes Rubinus, Bilus de Arca, Menegus calegarius. The last person also appears in Bartolomeo's registers: ASTv, Notarile, I, b. 33, Atti di Bartolomeo di Bernardo da Barbisano, f. 26r: [...] Menego calegario de Arca Collalti [...] (25th April 1375). The term arc(h)a castri clearly denoted the fortress (rocca), the very heart of the castle. See Passolunghi, P. A: Nota storico-insediativa, p. 18; idem: Le contee di Collalto, p. 58; cf. also the reconstruction by Potocnik, M. - Salvador, A.: Collalto, il castello delle origini, p. 23 (reproduced here as fig. 2).

32 Appendix I: Primo ad butifredum existens post habitacionis (sic!) Mercadanti fabri: Primo Mercada(n)tus faber.

33 Appendix I: Custodie deputate ad lobbiam pro custodia porte cum tocius castri. 
Arca, indicating that they lived in the castle. ${ }^{34}$ In addition, we know that Bonapace di Corrado di Collalto owned a house there, while a certain pelterer called Filippo had his home near the walls. ${ }^{35}$ Some of them may have been nobles, but the title of dominus is completely absent in this case.

On the dorse of the document is another long list of armed men, this time with their position within the castle's defence as well as the weapon they had. Therefore, it seems that this last list had a slightly different purpose compared with the preceding ones: while the first three indicated the regular shifts of the individual groups of guards for each day of the week, this long list determines the position of defenders of the castle only in the case of a siege, which was a highly unlikely situation. There is no need to go through this list in detail; it suffices to note that many of these people are identical with those from the second and third list who have been hypothetically identified as residents of the castle. This is further confirmed by the fact that many of the defenders here are indicated as actually being de Arca. We also have evidence of a group of guards defending the domus Tolberti while one of them was Tolberto di Sinisforte, undoubtedly the owner of the house in question and a castle resident, and the same applies to Antonio the barber and the aforementioned Merchadantus. ${ }^{36}$ On the other hand, many of the defenders are cited here for the first time, while others who were cited previously (e.g. the two Germans) are not listed here at all. In addition, we also find here some people from the first group who were identified as inhabitants of the villages subject to the castle. Nevertheless, this last list of armed men seems to represent almost exclusively the castle residents. Some of the guards were members of the noble families from the Trevigiano and the surrounding areas (e.g. Sinisforte, Onigo, Doglioni, Vidor), others were craftsmen, and we even find two clerics whose identification has already been discussed.

The following appendix to the list from 1st April 1373, on the other hand, presents a different situation. The defenders of the "new bastion" indicated here are almost exclusively the people from the first list. They were inhabitants of the villages surrounding the castle of Collalto, which is confirmed, among other things, by their epithets. Furthermore, in five cases, the individual names of the guards are specified by the note commorans in XY, meaning "living in", while each time it is either the village of Barbisano or Falzè.

The question is how to make sense of this rather contradictory information. No definite solution can be offered but, in spite of some ambiguities, I believe that the people

34 Johannes sartor de Arca; in the cases of Filipus peliparius, Bonapasius and Anthonius sartor, the epithet de Arca is indicated in the following list. These three men are also registered in Bartolomeo's notarial acts: ASTv, Notarile, I, b. 33, Atti di Bartolomeo di Bernardo da Barbisano, f. 10v, 11r (both 13th November 1374); f. 19v (6th January 1375); f. 29v (16th August 1375). Antonius quondam Nepotis lived in the village of Collalto: ibidem, f. 12v, 13r (both 22nd November 1374).

35 ASTv, Notarile, I, b. 33, Atti di Bartolomeo di Bernardo da Barbisano, f. 11r: [...] in archa Collalto, apud domum habitam per Bonapaxium quondam Conradi de Collalto [...] (13th November 1374). Appendix I: [...] post domum Filipi peliparii [...].

36 Appendix I: Ad custodiam poste fosse usque ad domum Tolberti cum domus Tolberti [...] ad butifredum existens post domum Anthonii barberii. Similarly, the commandry of the Order of St. John was also supposed to be defended by its members, i.e. by Brother Francesco and the other knights referred to as his familia. 
contained in the document can be basically divided into two groups: on the one hand, subjects from the villages and, on the other, inhabitants of the castle including the familia of the lord with some local nobles (vassals) and mercenaries, which is the garrison in the true sense of the word, as well as craftsmen, servants etc. ${ }^{37}$ Some of them were residents on a long-term basis, while others (for example the local priest) might have sought temporary refuge in the castle during the war. Both these groups participated in the defence of the castle in various ways. Whereas the first one, the villagers, probably had to come only once or twice a week to stand guard, some of the residents clearly had this duty too, but all of the residents were supposed to defend the castle in the case of a siege. $^{38}$

However, I still cannot explain why there were also some people from the villages listed among the defenders and, vice-versa, why there were residents standing guard with the villagers - in other words, why both groups of people partially merged. As the organisation of the defence had to be flexible, in some cases the members of the garrison were probably also supposed to reinforce the villagers and "supervise" them. Moreover, is possible that some of the villagers moved to the castle to serve there and thus became its residents, but whose names still used the original epithet of the village they came from. The appendix from April 1373 almost exclusively consists of villagers, so it seems that there were not enough members of the garrison to guard the newly built stronghold and thus this task fell upon the inhabitants of the villages. Nevertheless, these are all hypotheses and the whole question is still far from being resolved. One possible solution and a subject for future research could be an attempt to make a database to analyse these groups of people, or one might undertake a comparison of the situation at the castle of Collalto with other castles from the same period and area, provided that similar sources are extant.

It is difficult to say more about the social stratification of the people contained in these three lists. On the one hand, it is clear that some of them must have been nobles but, on the other, the title of Ser or Dominus does not seem to be used consistently, as it is missing in the case of some members of the local aristocratic families. There were few local clergymen. Chiarello Doglioni, a member of a noble family from Belluno, can be identified as at least one notary living in the castle. ${ }^{39}$ Many of the defenders of the castle are described as craftsmen, but there is no further information provided for the remainder. In addition, it has to be emphasized that our source illustrates quite well the "cosmopolitan" character of the garrison of the castle of Collalto, which housed not

37 Passolunghi, P. A.: Le contee di Collalto, p. 59, has pointed out generally that "[1]a lunga lista registra i servizi $[\ldots]$ a cui erano assoggettati gli uomini del castello e delle ville circostanti".

38 Other open questions have been raised in this context by Pier Angelo Passolunghi. See ibidem: "Non si è in grado di documentare le prestazioni o gli oneri bellici, che gravavano sui vasalli; di conseguenza non si è in grado di affermare se i residenti fossero vincolati a seguire il signore nelle operazioni militari esterne, o se il servizio armato si limitasse ai soli turni di vigilanza ai beni della comunità di appartenenza o, al più, dei centri vicini."

39 Appendix I: Item Clarelus not(arius) [...] Item Clarelus de Doyono. For the Doglioni family, see Sovilla, Marika: Struttura e potere della nobiltà di governo. La famiglia bellunese dei Doglioni nel Basso Medioevo. Master's Thesis. Università degli Studi di Padova, 1998, stored in Biblioteca Civica di Belluno. 
only people from the vicinity, but also from the whole of Veneto and Friuli, with some of them even coming from the regions on the other side of the Alps. ${ }^{40}$

\section{The castle's defence system}

The second issue is a reconstruction of Collalto Castle's defence system during the "Border War". In this case, we will focus our main attention on the instructions for the guards. Its text is divided into three sections according to the division of the first three lists of guards. The rules were clearly intended only for the custodie and scrivate standing guard every day; there is no reference to the possibility of a siege. Thanks to this source, it is possible to roughly reconstruct what a guard's ordinary shift at the castle of Collalto was like. The whole set of rules in fact only regulated the night watch when the castle was most vulnerable. Every evening after sunset, once the gate was closed, the guards were to gather in the hall, and from there they would be sent to their positions. ${ }^{41}$ This was to be completed by the tolling of the evening bell. One man at each position was to stand continually at the window and carefully watch outside. ${ }^{42}$ This meant there were several guards at each position who could switch being the lookout.

There was a somewhat enigmatic order instructing the guards to ask everyone approaching the castle for a nomen militis, which was probably some kind of "password" made up of a given male name. If the person in question did not answer or gave the wrong word, he or she was to be showered with stones without mercy. ${ }^{43}$ As will become apparent from the following dispositions, this password was changed every midnight, evidently in order to make it more difficult for an enemy trying to discover the code. I do not know of a similar system elsewhere, but there is no reason to suppose this was an invention unique to Collalto.

Only four people at the most were allowed to leave the castle - provided they knew the password - otherwise Count Rambaldo was to be informed of their departure. Obviously, there was the order that no one was allowed to climb the walls from the outside, whether or not they knew the password; in this case the guards were to throw stones at them, call for help and inform the lord. ${ }^{44}$ No one was to reveal the password under the severe penalty of torture while anyone trying to find it out was to be "strongly beaten". ${ }^{45}$

40 On the basis of local notarial registers from the castle of San Salvatore, it has been observed by Canzian, D.: Signorie rurali, p. 238-239.

41 Appendix I: Primo quod omnes custodie et scrivate veniant ad custodiam bona hora et saltim se presentent in occasu solis. Item predicte clausa janua castri se presentent subtus lobiam et tunc quilibet mittetur ad suam postam.

42 Ibidem: Item quod unus pro posta stet continue in pede ad fenestras, que respiciant extra muros potissime etc.

43 Ibidem: Item quod debeant scire nomen militis ab omnibus ascendentibus murum et ab omnibus euntibus extra muros, qui respondeant usque ad terciam vocem, aliter percuciantur cum lapidibus, et eciam si responderint et non dederint nomen proprium, quod percuciantur.

44 Ibidem: Item quod non permittant aliquem ascendere muros de extra nec cum schala, nec cum aliquo alio ordegno, eciam dando nomen proprium militis, et ipsos acriter percuciant et petant auxilium et denuncient domino Rambaldo.

45 Ibidem: Item quod aliquis non audeat dicere nomen militis datum sub pena torture nec similiter petere, et si aliquis velet scire nomen militis, quod percuciatur et fortiter et accusetur. 
Each man was to stay at his position, without shouting or "making vituperation". ${ }^{46}$ The guards were not allowed to leave their place until the morning bell was rung, whereupon they were to report to the hall.

There were also guards whose position brought additional responsibilities. This was especially true of the men in the big tower who were entrusted with supervising the guards on the walls. It was their responsibility to ensure everyone was in position after sunset. In addition, they were to periodically call the other guards - especially in the morning hours when everyone was more likely to fall asleep - and if there was no response, they were to corbelare these individuals (wake them up?). ${ }^{47}$ Again, they were the ones who were to ring the bell at sunset. There are also more references to the bellringing system, the sound of which signalled the beginning and the end of every night shift. ${ }^{48}$ Two other groups of guards, one of them next to the small gate (pusterna), were to allow everyone to go ad locum necessarium, i.e. to the toilet.

One paragraph was dedicated to the scrivate standing at the walls. They were also to report in the evening in the hall, then ascend the walls and wait for Count Rambaldo or his deputy who would give them the password (nomen militis). ${ }^{49}$ Two out of four of them were to guard diligently until midnight; there is no reference to the other two, but as they were supposed to patrol the walls until morning, they would probably have switched at that point. As with the others, they were to demand the password from anyone approaching the walls or going outside, but they were also to report any misconduct by the guards. ${ }^{50}$ Therefore, they seem to have had some kind of superior status in comparison with the ordinary guards who were mainly composed of villagers.

The third and last paragraph is dedicated to the guards ad lobiam. As with the scrivate, there were only four of them. Again, their shift started in the evening, when two of them were to stand guard until midnight, and the other two until morning. Their task was to stand at the hall and ask the password from anyone approaching the gate. Every

46 Ibidem: Item quod quilibet stet ad suam postam plano modo et non cridando et non canendo etc. Item quod aliquis non faciat vituperium super postis, nec super muris.

47 Ibidem: Item dicte custodie turis magne debent clamare omnes alias custod(ias) per spacium de eundo a porta castri usque quasi ad Muxile, sed per duas horas ante diem debeant clamare sepius et cum bona solicitudine et non respondentes corbelare. I was not able to translate the verb corbelare, which is later repeated in a noun form as corbela. In Italian, corbellare means "to ridicule someone", which seems to be absurd in this context. In our case, the most probable meaning of the word is to wake up the sleeping guards in some way.

48 For the important and multifarious function of bells within medieval society in general, cf. Borovský, Tomáš: Zvony a lidé středověkého města. Komunikační funkce zvonů v městské společnosti. In: Komunikace ve středověkých městech. Ed. M. Čapský. Opava 2014, p. 39-52.

49 Appendix I: Primo teneantur dicte scrivate se presentare hora superius denotata ad lobiam, ubi ponuntur custodie. Item teneantur predicte positis custodiis et pulsata campana turis magne ad sogam de sero ascendere muros et expectare dominum Rambaldum vel alium, qui det nomen militis ad postam orti. This passage may suggest that there were different passwords for different positions of the castle - in this case for a position next to a garden (hortus).

50 Ibidem: Item teneantur scire nomen militis ab omnibus ascendentibus ad muros de intus et ab euntibus extra muros, prout facere debent supradicte alie custodie deputate super postis. [...] Item teneantur dicte scrivate denunciare, si quid falli factum fuerit per custodias. 
inhabitant of the castle was allowed to go to the square (platea), but without weapons. ${ }^{51}$ Therefore, it seems that these men who watched the gate leading to the square actually guarded the castle against possible treason from within. Therefore, they would have to have been greatly trusted by Count Collalto. This is also confirmed by the fact that they were the ones to call Tolberto di Sinisforte or another competent person at midnight who would provide them, as well as the other guards, with a new password. ${ }^{52}$

In total, the castle was guarded by 26 armed men at night, who were periodically switched every day. 18 of them seem to have been villagers whose task it was to stay on the walls as well as in the towers, and they were supervised by four scrivate, also on the walls, and four "special" guards in the square. The last eight men, probably members of the ordinary castle garrison, seem to have been trusted more by the signore and, consequently, also enjoyed superior status. In spite of the fact that there is no reference in the entire document to the organization of guards during the day, this does not mean, of course, that the castle was not guarded then. Hypothetically, the surveillance of the castle during the day could be carried out by members of the ordinary garrison. As a result - unlike the inexperienced and less disciplined villagers - there was no reason to regulate their service by means of a special set of rules. In conclusion, the system of surveillance was in fact quite sophisticated and efficient.

In the case of a siege, all the male residents of the castle were to be mobilized. All the defenders on whom the lord of the castle could count were listed on the dorse of the document together with their position and weapon. In total there were approximately 130 armed men, ${ }^{53}$ while 42 defenders of the new bastion were added in April. This amounted to quite a considerable force. The troops were divided into small groups responsible for each position: along the walls, in the towers, bastions, by the gates etc. Count Rambaldo himself was defended by 30 men, while the commandry of the knights of St. John (mansio) was entrusted to its members, led by their commander, Brother Francesco. As crossbows and stones are often cited, these apparently constituted the principal defensive weapons of the garrison. However, there are also references to shooting weapons (sclopi) that had come into use in Italy from the first half of the Trecento. ${ }^{54}$

This list was clearly written in order to ensure that in the case of an assault, each man knew his position. However, it probably never came to this as the principal battles during the rest of the "Border War" took place in the territory of Padua. ${ }^{55}$ However, the Collalto lordships may have been the target of quick raids by Hungarian troops, as was reported in the Gatari chronicle, or points of passage for new military reinforcements coming to

51 Ibidem: Item dicte custodie non permittant aliquem ire versus portam transeundo cantonum fosse, nisi dederint nomen militis, sed super platea bene permittant omnes ire sine armis tamen.

52 Ibidem: Item teneantur vocare, quando erit dicta hora medie noctis, Tolbertum de Sinisforto vel Petrum eius fratrem vel Jacobum quondam Schenele pro maiori parte, qui det aliud nomen militis et ipsis et omnibus aliis custodibus.

53 Some places were left blank. In one case, for a change, only dominus Franciscus cum tota sua familia is cited. Therefore, it is not possible to count the exact number of defenders of the castle.

54 See Badalucchi, Ugo: Schioppo. In: Enciclopedia Italiana di scienze, lettere ed arti XXXI. Milano 1936 , p. 96-97.

55 Cf. Sambin, P.: La guerra. 
the Veneto from over the Alps via Friuli. The chronicler Raffaino Caresini suggests that the Venetian mercenaries staying in the Trevigiano could also have been a serious threat to the allies of the Republic of St. Mark. ${ }^{56}$ Therefore, the inhabitants of the castle of Collalto always had to be prepared for the worst.

As the document was amended in April 1373, this also means that it had been used, or at the very least, that it had been intended to be used. On the other hand, it seems somewhat strange that there are no marginal notes, corrections and so on. It is also possible that there were other auxiliary lists of guards which are now lost. However, given the destruction of the Collalto family archive held at the castle of San Salvatore, it is impossible to speculate more about any possible links between our document and other related sources.

The "combat regime" and the shifts of guards probably lasted until September 1373, when the war finally ended with a clear victory for Venice. One can only guess whether the document also played a role later on, for example, during the War of Chioggia (1378-1381), in which the Collalto sided once again with the Venetian Republic against the powerful alliance of Genoa, Louis of Hungary, Francesco Carrara and others. In spite of all the obscure or unresolved issues, the source we have analysed provides us with a unique insight into the daily life of an Italian late-medieval castle during a time of war.

56 Cf. Cronaca Carrarese. RIS NS XVII/1a, p. 94; Venetiarum Chronica. RIS NS XII/2, p. 24-25. 


\section{Appendix I: Edition}

The original document is preserved in Moravský zemský archiv v Brnĕ, G 169 - Rodinný archiv Collaltu Brtnice, folder 101, no. 2025.

Only some extracts from the as yet inedited document are to be found in Passolunghi, Pier Angelo: Nota storico-insediativa sulla località Collalto. Studi Trevisani 5/6, 1987, p. 17-19.

Note on the transcription:

I have tried to maintain the graphic layout of the document as much as possible. In order to do so, the single names of guards have been typeset in a smaller font. The notes have been omitted, as there are basically no corrections in the text. Abbreviations have been expanded and, when deemed necessary, put into round brackets - especially in the case of names.

Diacritical signs:

[] damage of the document

() expanded abbreviations or emendations

<> crossed out text

*** omitted text 
[recto]

In Christi nomine amen. Millesimo CCCLXXIII, indictione $\mathrm{XI}^{\mathrm{a}}$, die primo Januarii. Infrascripte sunt custodie deputate $\mathrm{a}[\mathrm{d}]$ custodiam castri Collalti et cum quo ordine et cum qua forma et in quo loco et ad quod officium et quo die debent venire.

Prima die Dominico de sero:

Primo Ser Jacobus de Costis

Item Ser Benucius

Item Ser Guecelus

Item Andreas

Item Seravalus

Item Johannes Tibaldus

Primo Somaritanus

Item Barth(olomeu)s quon-

dam Moltoni

Item Barth(olomeu)s de

Zapare

Primo Guecelus de Bar-

bix(ano)

Item Vivencius de Barbix(ano)

Item Rigus quondam Petri

Certi

Primo Ticianus de Honedo Primo Zanonus faber

Item Leonardus de Honedo Item D(omi)nicus

Item Bortolus de Honedo quondam Minati

Item Yvanus de Honedo Item Barth(olomeu)s

Item Chinatus de Falz(edo) a Vanis

Item Vivencius de Mazo

Item Johannes Ronconus

Item Bonatus de Falz(edo)

Item Pasqualinus

Quinta die Jovis de sero:

Primo Nascimbene quondam Ser Todo

Item Targa de Sernaya

Item Ser Scilius dicti loci

Item Bortolus quondam

Ser Todo

Item Ser Pupus de Sernaya Item Targa de Sernaya

Item Rossonus de Sernaya

Primo Ticianus de

Refrent(olo)

Item Rizardus

Item Ordanus

Primo Victor de

Barbix(ano)

Item Beteus de

Item Bernardus
Sexta die Veneris de sero:

Primo Barth(olomeu)s de

Sulico

Item Cavalenus

Item Simeonus

Primo Tonsus de Vale

Item Tibaldus

Primo Marcus de Bor

Item Jacobus de Bolo

Item Pasqualinus del Goto

Primo Gerardus de Fara

Item Jacobus quondam Ser

Lauren(cii)

) Item Dominicus quondam

Gambore
Tercia die Martis de sero:

Primo Tonsus de Vale

Item Franciscus de Cam-

pagna

Item Laurencius de Bus-

tedo

a) Item Zerius Johannis

Longi

Item Leonardus de Perezo

Item Michael de Giuxa

Primo D(omi)nicus quondam Alding

Item Gulicus del Sclava

Item Barth(olomeu)s quon- Primo Franciscus quon-

dam Pizo

Primo Jacobus de Rayna

Item Katarinus de Rayna

Item Andreas de

Barbix(ano)

Primo Bertolucius quon-

dam Masqua

Item Bertolucius de Lati-

era

Item Zampupus

Item Johannes a Navi

Item Maroza

Item $\mathrm{D}$ (omi)niginus

Septima die Sabati de sero:

Primo Castregnanus

Item Franciscus Ser

Jaco(bi)

Item Guarnerius

Item magister Petrus

Item Jacobus Bernardi

Item Franciscus de Patrya

Primo Benedictus de

Refrent(olo)

Item Bonus de

Refrent(olo)

Item Vendraminus

Primo Minetus de Bar-

bix(ano)

Item Anthonius quondam

Vencii

Item Anthonius quondam

Mini
Quarta die Mer(curii) de sero:

Primo Jacobinus quondam

Ser Menegi

Item Pax ab Eccl(es)ia

Item Bezenus de Sernaya

Item Ser Johannes de

Sernaya

Item Tibaldus de Sernaya

Item Serafinus de Sernaya

Primo Petrus de Lamira

Item Franciscus dicti loci

Item Plevanelus

dam Beti

Item D(omi)nicus quon-

dam Ser Fini

Item Rigus quondam

Bazede

Primo Laurencius de Falz(edo)

Item Moretus Buschi

Item Vivencius quondam

Uberti

Item Zambonus

Item Rizardus

Item Tonsus de Laveza 


$\begin{array}{lll}\text { Primo Barth(olomeu)s } & \text { Primo Minus a Fologno } & \text { Primo Petrus de Colalbrico } \\ \text { Baratinus } & \text { Item Paulus quondam } & \text { Item Ser Giudo dela Cru } \\ \text { Item Fiyassinus } & \text { Cataney } & (?) \\ \text { Item Ubertus } & \text { Item Johannes Matara } & \text { Item Johannes sartor } \\ \text { Item Cardinalis } & \text { Item Meniega } & \text { Item Manfredus Papa } \\ \text { Iten Francesconus } & \text { Item D(omi)nicus quon- } & \text { Item Petrus sartor } \\ \text { Item Leonardus quondam } & \text { dam Grui } & \text { Item Marosteganus } \\ \text { Tonsi } & \text { Item Rubeus a Doigale } & \end{array}$

Scrivate deputate super muros castri Collalti ut infra per ordinem:

$\begin{array}{lll}\begin{array}{l}\text { Primo die Dominico de } \\ \text { sero: }\end{array} & \begin{array}{l}\text { Secunda die Lune de } \\ \text { sero: }\end{array} & \begin{array}{l}\text { Tercia die Martis de sero: } \\ \text { Primo dominus frater }\end{array} \\ \begin{array}{l}\text { Primo dominus Rambaldus Franciscus de Sulico } \\ \text { Item Blasius sartor }\end{array} & \begin{array}{l}\text { Primo dominus presbyter } \\ \text { Barth(olomeu)s }\end{array} & \begin{array}{l}\text { Franciscus } \\ \text { Item Alpretus de Meduno }\end{array} \\ \begin{array}{ll}\text { Item Barbixanus faber } \\ \text { Primo Leonardus de Arca } \\ \text { Item Anthonius Batayi }\end{array} & \begin{array}{l}\text { Taxinonus } \\ \text { Item Odoricus becarius }\end{array} \\ \begin{array}{lll}\text { Quinta die Jovis de sero: } & \text { Sexta die Veneris de sero: } & \text { Septima die Sabati de } \\ \text { Primo frater Paulus } & \text { Primo Marconus } & \text { sero: } \\ \text { Item Sabadinus } & \text { Item Clarelus not(arius) } & \text { Primo Barth(olomeu)s } \\ \text { Primo Johannes calegarius } \\ \text { Item Johannes Rubinus }\end{array} & \begin{array}{l}\text { Item Martinus de Larosa } \\ \text { Item Merchadantus }\end{array} & \begin{array}{l}\text { Item Famulus Ser Rizardi } \\ \text { Primo Bilus de Arca }\end{array} \\ & & \text { Item Menegus calegarius }\end{array}$

Quarta die Mer(curii) de sero:

Primo Prevedelus

Item Johannes a Barba Primo Marinus peliparius Item Barth(olomeu)s quondam Hensedisii

Custodie deputate ad lobiam pro custodia porte et tocius castri:

Prima die Dominico de
sero:
Primo Bernardus de Sulico
Item Nicolaus de Attims
Item Conadus de Cesana
Item Daniel de Pad(ua)
Quinto die Jovis de sero:
Primo Barth(olomeu)s
quondam T.
Item Barth(olomeu)s de
Sancto Daniele
Item Johannes sartor de
Arca
Item ***

Prima die Dominico de Primo Bernardus de Sulico Attims Item Conadus de Cesana

Secunda die Lune de
sero:
Primo Jacobus de Fagedis
Item Ulricus Teotonicus
Item Altinetius de Vido
Item Filipus peliparius

Sexto die Veneris de sero: Primo Odoricus de Sacilo Item ***

Item Federicus de Brazado

Item Tolbertus de Vonico
Tercia die Martis de sero: Primo Bonapasius Item Ulricus Teotonicus Item magister Dodus Item Bertolucius sartor
Quarta die Mer(curii) de sero:

Primo unus ex scutiferis Item Johannes Teotonicus Item Johannes de Lugo Item Anthonius sartor

Millesimo, indictione et die predictis. Infrascript(us) est ordo et regula datus et data predictis custodiis et scrivatis deputatis ad custodiam castri Collalti per dominum Rambaldum de Collalto, comitem Ter(visinum) et primo custodiis muri.

Primo quod omnes custodie et scrivate veniant ad custodiam bona hora et saltim se presentent in occasu solis.

Item predicte clausa janua castri se presentent subtus lobiam et tunc quilibet mittetur ad suam postam.

Item quod omnes deputati ad suas postas inveniantur in suis postis de sero pulsata campana turis. 
Item quod unus pro posta stet continue in pede ad fenestras, que respiciant extra muros potissime etc.

Item quod debeant scire nomen militis ob omnibus ascendentibus murum et ab omnibus euntibus extra muros, qui respondeant usque ad terciam vocem, aliter percuciantur cum lapidibus et eciam si responderint et non dederint nomen proprium, quod percuciantur. Item quod permittant omnes ire extra muros usque ad quatuor dando nomen militis et si fuerint plures et dederint nomen militis, quod teneantur denunciare domino Rambaldo de presenti.

Item quod non permittant aliquem ascendere muros de extra nec cum schala, nec cum aliquo alio ordegno, eciam dando nomen proprium militis, et ipsos acriter percuciant et petant auxilium et denuncient domino Rambaldo.

Item quod aliquis non respondeat nisi pro sua posta, aliter cadit ad penam triplicatam et ultra etc.

Item quod aliquis non audeat dicere nomen militis datum sub pena torture, nec similiter petere et si aliquis velet scire nomen militis, quod percuciatur et fortiter et accusetur.

Item quod quilibet stet ad suam postam plano modo et non cridando et non canendo etc.

Item quod aliquis non faciat vituperium super postis, nec super muris.

Item quod aliquis non descendat de sua posta, nisi quando pulsatur campana cum soga de mane et se presentent ad lobiam.

Primo quod custodie stantes ad toreselam debeant omni mane respicere, si erit factum aliquod vituperium super postis et muris et si quid invenerint, quod denuncient de presenti.

Item quod custodie stantes ad postam figerii possint descendere pro solvendo debitum nat(ural)e et permittant omnes ire ad locum etc.

Item quod custodie stantes ad postam pusterne permittant omnes ire ad locum necessarium.

Primo quod custodie ascendentes ad turim magnam debeant pulsare campanam parvam cum soga per longum spacium ante occasum solis aliquantulum et postea in occasu solis iterum pulsare et tunc omnes custodie debeant venisse (sic!).

Item quod dicte custodie turis magne positis custodiis debent pulsare campanam parvam cum soga per aliquod spacium et tunc finita pulsatione campane omnes alie custodie debeant esse ad suas postas.

Item dicte custodie turis magne debent clamare omnes alias custodias per spacium de eundo a porta castri usque quasi ad Muxile, sed per duas horas ante diem debeant clamare sepius et cum bona solicitudine et non respondentes corbelare.

Item quod unus ex custodiis turis magne debeat descendere ante pulsationem et manifestare omnes corbelas.

Item quod alia custodia remanens super turim debeat pulsare campanam parvam, quando sibi denunciatur, ut alie custodie descendant de suis postis ordinate.

Item quod custodie turis magne non debeant pulsare mediam noctem, nisi custodes porte castri sibi dixerint et illi dicant de mandato custodiarum deputatarum ad lobiam etc. 
Ordo et regula dat(us) scrivatis deputatis ad muros:

Primo teneantur dicte scrivate se presentare hora superius denotata ad lobiam, ubi ponuntur custodie.

Item teneantur predicte positis custodiis et pulsata campana turis magne ad sogam de sero ascendere muros et expectare dominum Rambaldum vel alium, qui det nomen militis ad postam orti.

Item teneantur due ex ipsis facere custodiam usque ad mediam noctem et una ex ipsis stet continue in pede a parte inferiori poste orti et alia a parte superiori faciendo bonam custodiam et specialiter de extra eundo et redeundo per supra muros et non cridando. Item teneantur scire nomen militis ab omnibus ascendentibus ad muros de intus et ab euntibus extra muros, prout facere debent supradicte alie custodie deputate super postis.

Item non descendant de muris, nisi quando pulsatur campana parva turis magne de mane.

Item teneantur dicte scrivate denunciare, si quid falli factum fuerit per custodias.

Ordo et regula dat(us) custodiis deputatis ad lobiam:

Primo teneantur dicte custodie se presentare ad lobiam hora debita, prout facient alie custodie.

Item due ex ipsis faciant bonam custodiam usque ad mediam noctem et alie due post mediam noctem stando in pede sub lobia et cum suis armis.

Item dicte custodie non permittant aliquem ire versus portam transeundo cantonum fosse, nisi dederint nomen militis, sed super platea bene permittant omnes ire sine armis tamen.

Item teneantur, quando erit media nox et hora debita, facere pulsare mediam noctem cum campana parva etc.

Item teneantur vocare, quando erit dicta hora medie noctis, Tolbertum de Sinisforto vel Petrum eius fratrem vel Jacobum quondam Schenele pro maiori parte, qui det aliud nomen militis et ipsis et omnibus aliis custodibus.

[verso]

[I]n Christi nomine amen. Millesimo CCCLXXIII ${ }^{\circ}$, indictione $\mathrm{XI}^{\mathrm{a}}$, die primo Januarii. Infrascripti sunt homines deputati ad custodiam tocius castri Collalti et in quibus locis pro defensione dicti castri cum suis armis.

Ad custodiam turis magne cum balistis et lapidibus:

Primo Jacobus quondam S. (?) $=$ Item Reprandinus filius Dodi. $=$ Item $* * *$

Ad custodiam poste pistorie cum sclopis et balistis:

Primo Alexander Muratius. $=$ Item Alpretus de Meduno. $=$ Item $* * *$

Ad custodiam poste coquine cum sclopis et balistis:

Primo Ser Zanetus de Glavra. = Item Bortolucius sartor. $=$ Item *** 


\section{Ad custodiam palacii novi:}

Primo Johannes Franciscus. $=$ Item Bernardus de Sacilo. $=$ Item Franciscus pistor. $=$ Item Petrus de Honedo de Falz(edo). = Item ***

Ad custodiam porte castri de intus:

Primo Odoricus de Sacilo. = Item Ulricus de Tolino. = Item Bertolus de Honedo. = Item Jacobus quondam Ser Laurencii de Barbix(ano).

Ad custodiam porte castri de foris:

Primo Petrus de Sinisforto. = Item Nicolaus de Attims. = Item Barth $($ olomeu $)$ s de Sancto Daniele. = Item Altinerius de Vidoro. = Item nepos Chinati de Falz(edo). = Item Victor de Barbix(ano).

Ad custodiam muri castelani lobie usque ad campanile et ad campanile: Primo *** Item Clarelus de Doyono. = Item Bonapasius de Arca. = Item Johannes de Tolino. = Item Conadus de Cesana. $=$ Item Prevedelus. $=$ Item Benevenutus filius Petri sartoris. $=$ Item filius Pasqualini de Falz(edo). = Item Tonsus de Vale de Sernaya.

\section{Ad custodiam mansionis:}

Primo dominus Franciscus cum tota sua familia.

Ad custodiam poste fosse usque ad domum Tolberti et domus Tolberti:

Primo Tolbertus de Sinisforto. $=$ Item Petrus sartor de Sernaya. = Item Marconus de Foresto. $=$ Item Laurencius de Vidoro. = Item Johannes de Labarba. = Item Daniel de Padua. = Item Anthonius sartor de Arca. = Item Anthonius quondam Nepotis. = Item Bertolucius de Latiera de Falz(edo). = Item Leonardus de Perezo de Sernaya.

Ad custodiam poste toresele et poste figerii et poste orti et ad muros de intus istarum postarum:

Primo Barth(olomeu)s quondam Tolberti. = Item Bernardus de Sulico. = Item Barth(olomeu)s Taxinonus de Arca. = Item Barbixanus faber. = Item Johannes sartor de Arca. = Item Johannes Rubinus de Arca. = Item magister Filipus peliparius de Arca. $=$ Item nepos Vivencii quondam Uberti de Falz(edo). = Item Johannes Tibaldus. = Item Johannes de Frata. = Item ***

Ad custodiam poste talponi et poste pusterne et murorum a posta orti superius: Primo magister Dodus. $=$ Item Johannes eius filius. $=$ Item Anthonius Bataxinus. $=$ Item Johannes calegarius de Arca. = Item Simeon calegarius. = Item Ser Sabadinus de Castro. = Item filius Barth(olome)i becarii. = Item filius Zamboni de Falz(edo). = Item Jacobinus quondam Ser Menegi de Sernaya. = Item Petrus de Rayna de Barbix(ano). $=\langle$ Item Petrus filius Belucii de Refrent(olo). $\rangle$ = Item Benedi(c)tus de Refrent(olo).

\section{Ad custodiam persone domini Rambaldi:}

Primo dominus Rambaldus. = Item Ser Rizardus de Sulico. $=$ Item dominus plebanus de Sernaya. $=$ Item dominus presbyter Barth(olomeu)s de Barbix(ano). = Item Ser Gabriel de Solagna. = Item Fe- 
dericus de Brazado. = Item Jacobus de Fagedis. = Item Ulricus de Ragisbuors (?). = Item Tolbertus de Vonico. = Item Johannes de Lugo. = Item Franciscus de Sulico. = Item Stefanus scutifer. $=$ Item Barth(olomeu)s filius Ser Zaneti de Glavra. = Item Barth(olomeu)s becarius. = Item Ticianus de Honedo. = Item Paulus de Braydo. = Item Leonardus quondam Tonsi de Falz(edo). = Item D(omi) nicus frater Fiyassini (?). = Item filius Petri fratris Bixani de Sernaya. = Item Michael de Guixa. = Item Rossonus de Sernaya. = Item Jacobus filius Ser Salii de Sernaya. = Item Jacobus filius Leonardi de Spontono de Refrent(olo). = Item filius Algurini de Refrent(olo). = Item Petrus de Lamira. = Item Petrus de Bollono. = Item Vivencius de Barbix (ano). = Item Laurencius filius Bernardi de Barbix (ano). = Item Martinus de Valle Lupi. = Item Corbanesius de vila Collalti.

Ad custodiam arche castri Collalti murate:

Primo ad turim sancti Georgi: Primo Daniel de Padua. = Item Barth $($ olomeu $)$ s peliparius. = Item Bertolucius filius Ser Benucii. = Item filius Pacis de Sernaya

Primo ad butifredum situatum iuxta tabernam: Primo Marinus peliparius. = Item Bortolus frater Cavalerii de Sernaya.

Primo ad butifredum existens in curtivo done ture: Primo Blasius sartor de Arca. = Item Vendraminus nepos quondam Johannis de Sernaya.

Primo ad butifredum existens post domum Filipi peliparii: Primo Leonardus de Arca. $=$ Item filius D(omi)nici de Gabarelo de Barbix(ano).

Primo ad butifredum existens post quondam Rubini (sic!): Primo Mateus quondam Hensedisii de Arca. $=$ Item filius Maroze de Falzedo.

Primo ad butifredum existens post domum Anthonii barberii: Primo Barth(olomeu)s peliparius quondam Hensedisii de Arca. = Item Minus filius Uberti de Falz(edo).

Primo ad butifredum existens post domum habitationis Johannis sartoris: Primo Billus de Arca. = Item D(omi)nicus filius Cardinalis.

Primo ad butifredum existens post habitacionis (sic!) Mercadanti fabri: Primo Mercada(n)tus faber. $=$ Item famuli dicti Mercadanti. $=$ Item Paulus quondam Cataney de Falz(edo).

Primo ad turim sancti Martini dicte arche: Primo Anthonius barberius. = Item Guasparinus de Arca. = Item Menegus calegarius de Arca. = Item Johannes filius Francisci de Lamira de Refrent(olo).

Primo ante domum quondam Rubini pro sucurendo aliis: Primo Reprandinus gastaldus. $=$ Item Cristanus de Arca. = Item Odoricus becarius. = Item Martinus de Feleto. $=$ Item Petrus filius Ser Pupi de Sernaya. = Item Guecelus de Barbix(ano). = Item Moretus filius Betey de Barbix(ano). = Item D(omi)nicus quondam Grui de Falz(edo). = Item Marcus de Borbeyago de Refrent(olo).

Primo ad custodiam resteli de Corbazono: Primo Nicolaus de Vonico.

Primo ad custodiam resteli a lavadoro: Primo Pupus de Sub Croda (?).

Ad custodiam bastie nove dato ordine die primo Aprilis in dicto millesimo: Primo ad custodiam prime entrestale prope Muxile: Primo Rielus de Falz(edo). = Item Meretus filius Buschi. = Item Zampupus de Falz(edo). = Item Zerius Johannis Longi de Sernaya. = Item Barth(olomeu)s quondam Moltoni de Refrent(olo). 
Primo ad custodiam secunde entrestale iuxta portam muxilis: Primo Vendramus a Donigale. $=$ Item Petrus de Colalbrico commorans in Falz(edo). = Item Marosteganus de Falz(edo). = Item Laurencius de Bustedo de Sernaya. = Item Barth(olomeu)s de Cusignana.

Primo ad custodiam resteli: Primo Bortolus de Rigolino. = Item Zanonus faber de Falz(edo). = Item D(omi)nicus quondam Ser Fini de Barbix(ano). = Item D(omi)nicus quondam Aldigerii de Refrent(olo). = Item Vendraminus de Refrent(olo).

Primo ad custodiam primi butifredi prime porte et per totam illam spinatam usque ad cantonum: Primo Johannes Matetacius de Falz(edo). = Item Tibaldus de Sernaya. = Item Andreas de Barbix(ano). = Item Bonus de Refrent(olo).

Primo ad custodiam secundi butifredi secunde porte: Primo Manega de Falz(edo). = Item Nascimbene quondam Ser Todoverti de Sernaya. = Item Franciscus de Cayrano commorans in Barbix(ano). = Item Barth(olomeu)s quondam Pizolati de Refrent(olo).

Primo ad custodiam tercii butifredi situati in cantono bastie versus montem: Primo filius Ser Andree Tonsi de (sic!) commorans in Falz(edo). = Item Targa de Sernaya. = Item Franciscus quondam Beti de Barbix(ano). = Item Rizardus de Refrent(olo).

Primo ad custodiam quarti butifredi situati in capite prati quondam Rubini sub postam figerii: Primo Vivencius de Mazochonibus de Falz(edo). = Item Barth(olomeu)s de Zaparelo de Refrent(olo). Primo ad custodiam prime betresche et magis alte super viam versus domum quondam gastaldi: Primo filius Rizardi del Zussa de Falz(edo). = Item Meneginus de Labilia de Barbix(ano). = Item Bertoldus de Refrent(olo).

Primo ad custodiam secunde betresche ita descendendo versus sero: Primo Bertolucius quondam Masquagnini commorans in Falz(edo). = Item Vendraminus de Barbix(ano). = Item Martinus del Sclava de Refrent(olo).

Primo ad custodiam tercie betresche ita descendendo versus sero super burifredum prime porte: Primo Barth(olomeu)s Baratinus de Falz(edo). = Item Guarnerius de Sernaya. = Item Pasqualinus Spontonus de Refrent(olo).

Primo ad custodiam quarte bertresche, que est super restelum: Primo Tonsus de Lavenza de Fal$\mathrm{z}($ edo). = Item Bortoluc(ius) quondam Ser Todoverti de Sernaya. = Item Gerardus de Fata commorans in Barbix(ano). = Item Bezenus de Sernaya.

[...] continens custodias omnes deputatas pro custodia [ca]stri Collalti millesimo CCCLXXIII, tempore [gu] ere inter dominacionem ducalem et dominum Padue. 


\section{Appendix II: Figures}

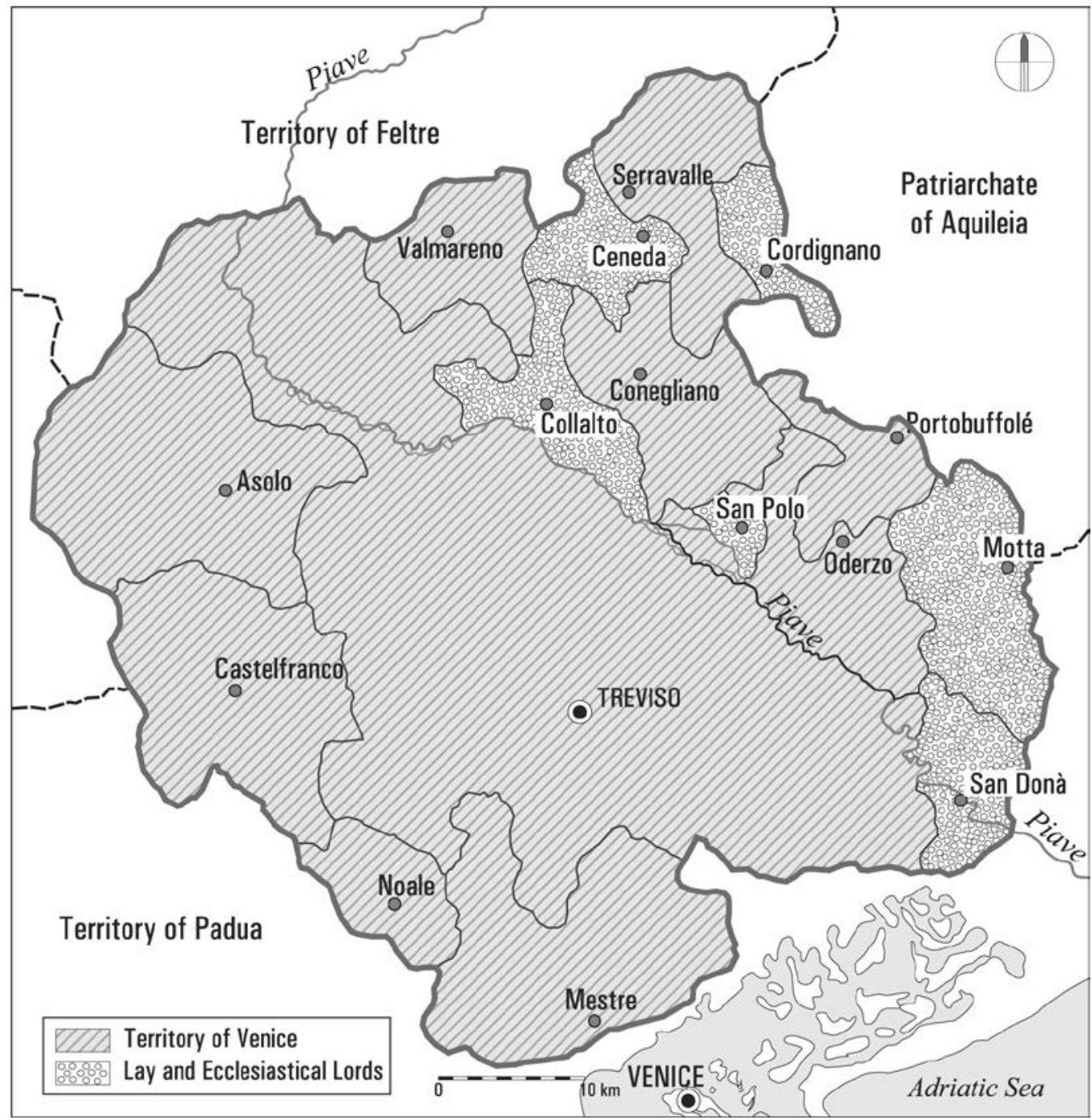

Fig. 1: A map of the Trevigiano in the 1370s (based on // Veneto nel medioevo. Le signorie trecentesche. Edd. A. Castagnetti - G. M. Varanini. Verona 1995, p. 87, fig. 58, created by Jaroslav Synek). 


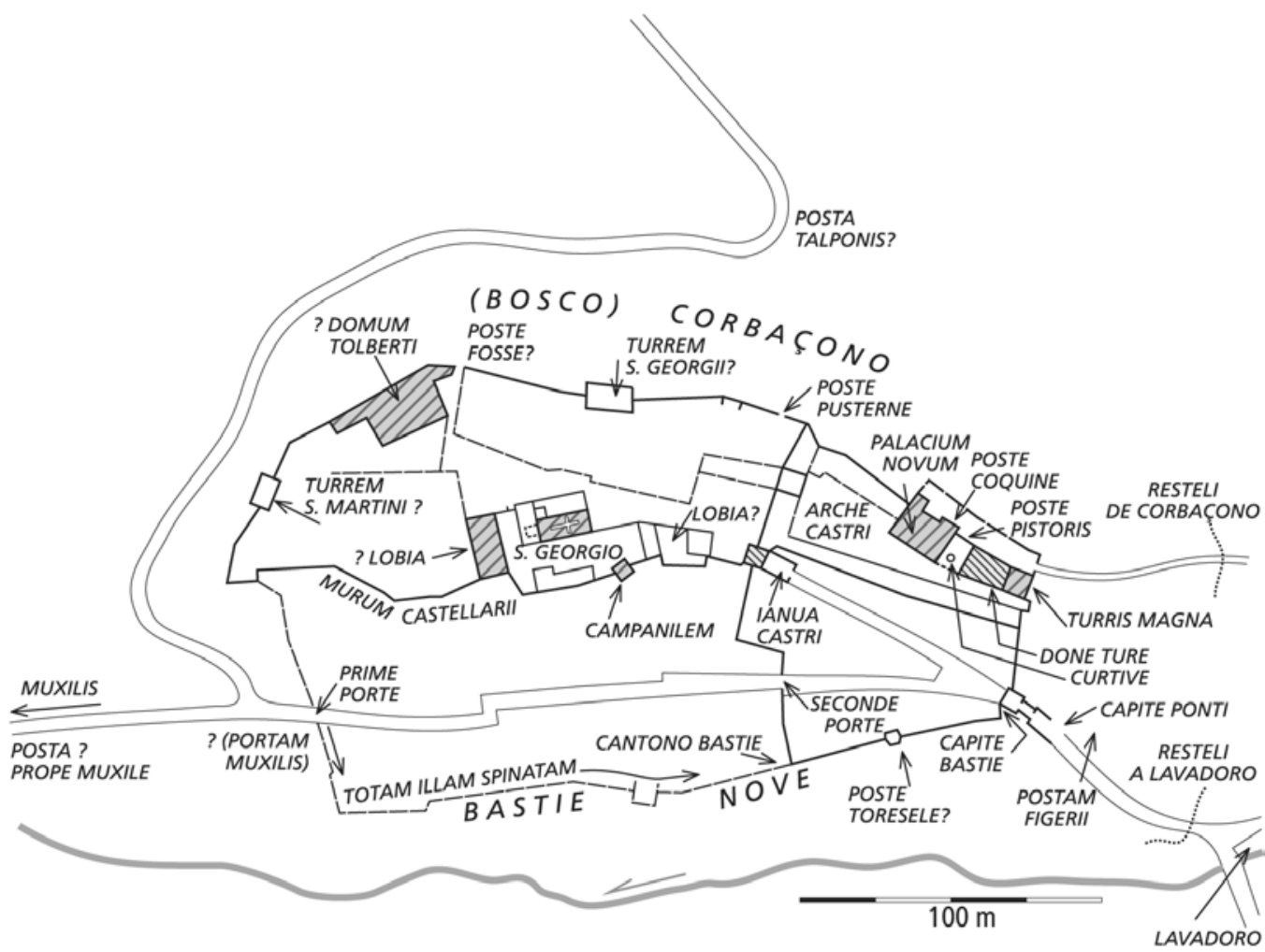

Fig. 2: A reconstruction of the ground plan of the castle of Collalto in 1373 (based on Potocnik, Michele - Salvador, Antonio: Collalto, il castello delle origini, e la chiesa di San Daniele di Colfosco o di San Salvatore. In: 958-1998. I Collalto. Conti di Treviso, patrizi veneti, principi dell'Impero. Atti del Convegno, 23 maggio 1998, Castello di San Salvatore, Susegana. Ed. Circolo Vittoriese di Ricerche Storiche, Vittorio Veneto 1998, p. 23, created by Jaroslav Synek). 

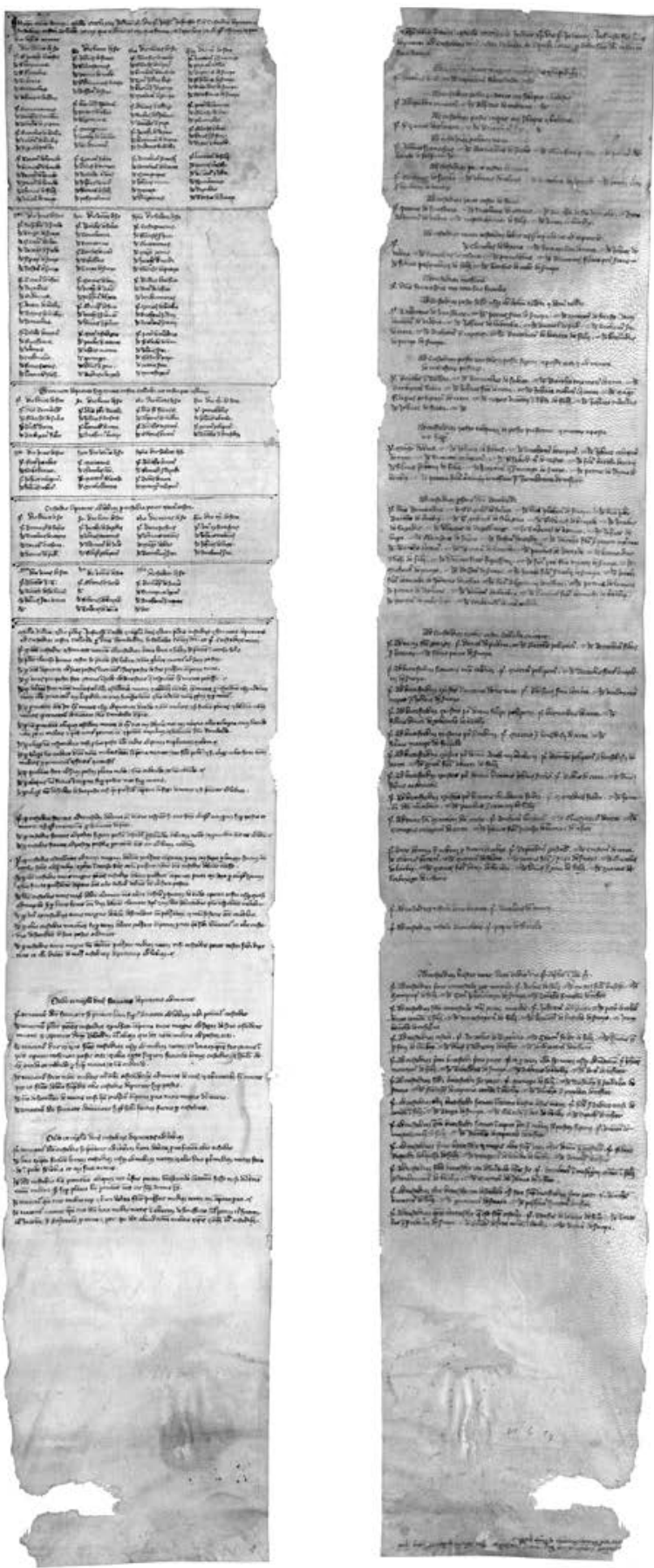

Fig. 3a-b: The list of guards and defenders of the castle of Collalto with the set of rules for them from 1373 (Moravský zemský archiv v Brně, G 169 - Rodinný archiv Collaltů Brtnice, folder 101, no. 2025; photo: Moravský zemský archiv). 


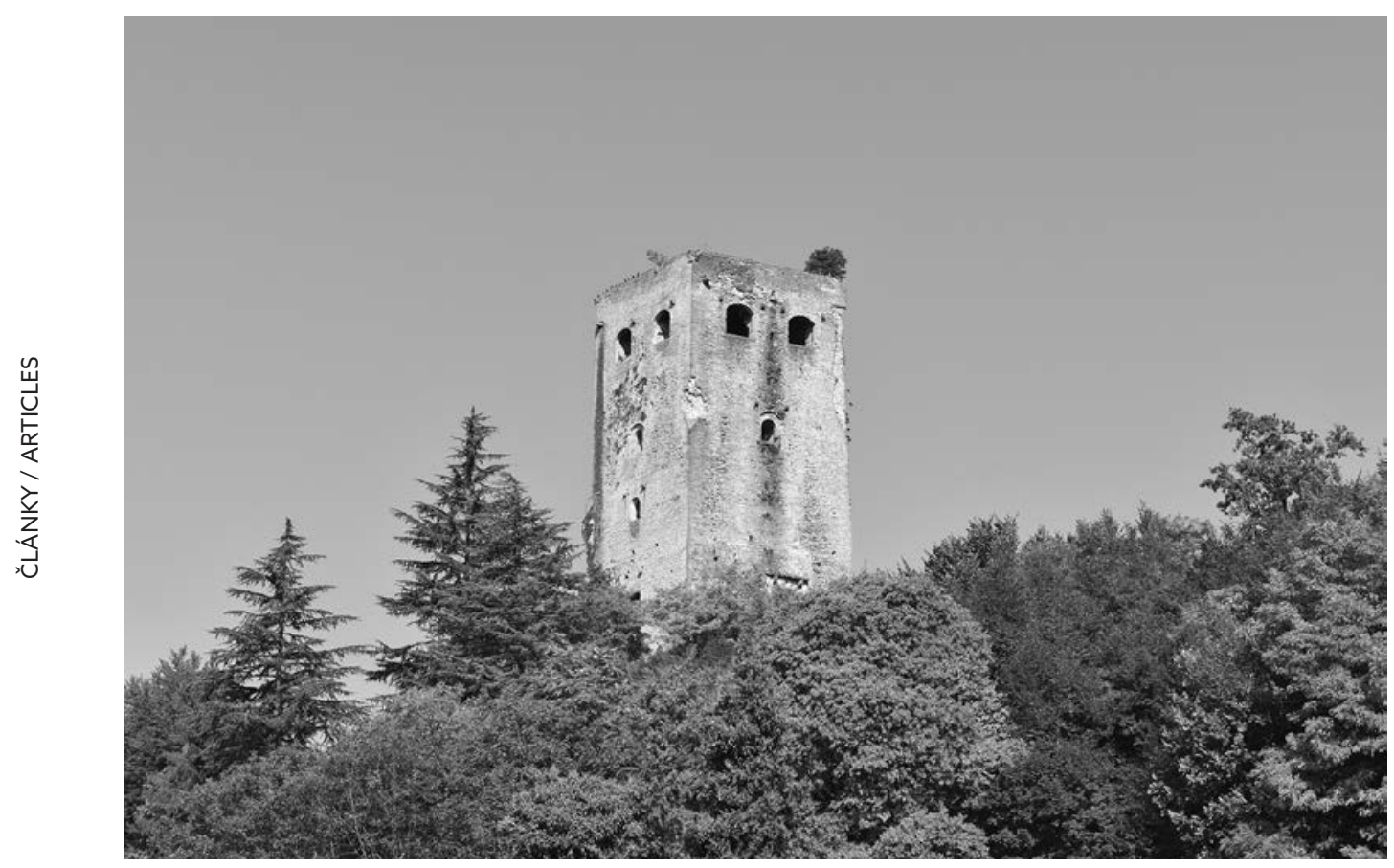

Fig. 4: The "big tower" of the castle of Collalto today (photo: Ondřej Schmidt).

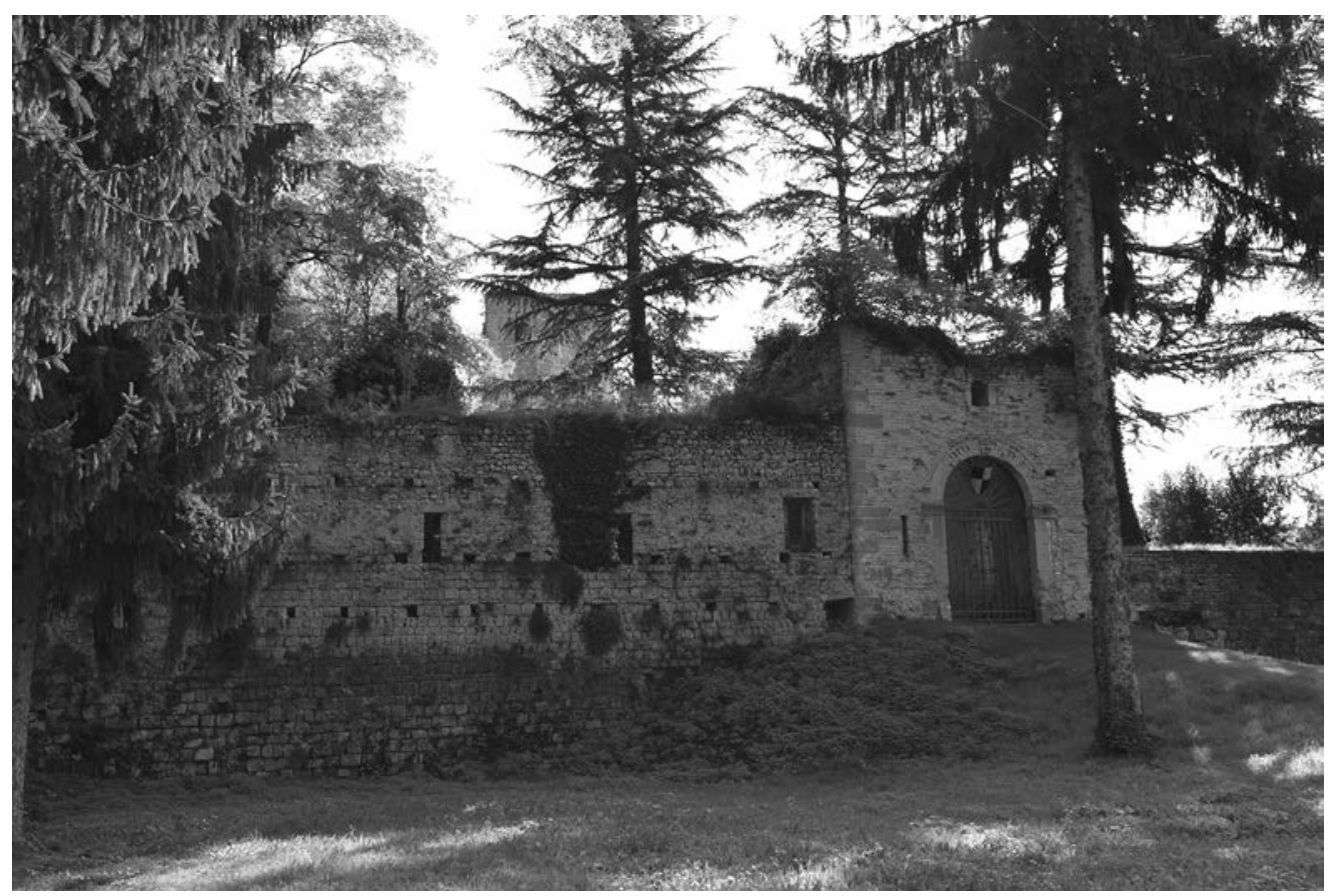

Fig. 5: The walls of the castle of Collalto today (photo: Ondřej Schmidt). 


\section{Hrad Collalto ve válce: sociální struktura posádky a obranný systém $v$ roce 1373}

V centru pozornosti této studie je pozoruhodný pramen, dochovaný shodou okolností v Moravském zemském archivu v Brně, který nabízí neotřelý vhled do každodenního života na pozdně středověkém italském hradě v době války. Jedná se o soupis stráží a dalších obránců hradu Collalto (severně od Trevisa) z roku 1373, jehož součástí je též řád posádky. První doklady o existenci hrabat z Trevisa, později známých pod predikátem z Collalta a San Salvatore, pocházejí již z poloviny 10. století. Podobně jako další markraběcí a hraběcí dynastie ani hrabata z Trevisa nedokázala prosadit svou autoritu na území jim svěřeného hrabství. To vyústilo v postupný přesun těžiště rodové moci na venkovská panství na řece Piavě, jejichž součástí se stal i hrad Collalto.

Ve 14. století se hraběcí državy, formálně autonomní ř́řsská léna, nacházely pod tlakem okolních expandujících mocností - především Benátské republiky a rodu Carrara z Padovy. V letech 1372-1373 pak probíhala tzv. „pohraniční válka“, do níž se na straně Carrarů zapojil též uherský král Ludvík Veliký. Collaltové v tomto konfliktu stáli na straně Republiky sv. Marka, přičemž jejich území se přinejmenším jednou stalo dějištěm bojů. Nepochybně právě tyto okolnosti vedly k tomu, že hrabě Rambaldo IX., tehdejší pán Collalta, nechal sepsat soupis a řád posádky za účelem zefektivnění obrany hradu.

Vlastní pramen, který má formu podlouhlého, z obou stran popsaného pergamenu, využila dosavadní historiografie převážně jen k rekonstrukci podoby hradu Collalto ve 14. století. Oproti tomu se tato studie pokouší analyzovat jiné dva aspekty: sociální strukturu posádky a obranný systém hradu. Údaje z jednotlivých seznamů bohužel nedovolují vždy určit v nich obsažené osoby, ani zjistit jejich původ či vzájemný vztah. Přesto se snad podařilo identifikovat dva základní okruhy strážných: na jedné straně to byli vesničané z okolních poddaných vsí hradního panství, na straně druhé pak stálá posádka a další obyvatelé hradu. Samostatnou položku představuje řád posádky, na jehož základě lze rekonstruovat poměrně sofistikovaný systém obrany hradu v době „válečné pohotovosti“ včetně systému střídání stráží, periodického stanovování hesla pro vstup do hradu a aspekty výzbroje obránců. 
